\title{
Criminal act provision of psychic violence on wife in household scope
}

\author{
Sri Nurfadillah DH Pasha ${ }^{1}$, Muhadar ${ }^{2}$, Haeranah ${ }^{3}$.
}

${ }^{1}$ Sri Nurfadillah DH Pasha; Pascasarjana Hukum, Universitas Hasanudin Jl. Perintis Kemerdekaan KM 10, Makasar, 90245, Indonesia. (0411) 587219.

${ }^{2}$ Muhadar; Pascasarjana Hukum, Universitas Hasanudin Jl. Perintis Kemerdekaan KM 10, Makasar, 90245, Indonesia. (0411) 587219.

${ }^{3}$ Haeranah; Pascasarjana Hukum, Universitas Hasanudin Jl. Perintis Kemerdekaan KM 10, Makasar, 90245, Indonesia. (0411) 587219.

\section{ARTICLEINFO}

Article history:

Received 2020-09-30

Received in revised form

2020-10-11

Accepted 2020-12-01

\section{Kata kunci:}

Pembuktian; Kekerasan Psikis;

Visum et Repertum Psikiatrikum.

\section{Keywords:}

Proof; Psychic Violence; Visum et Repertum Psychiatricum.

DOI: https://doi.org/10.26905/ idjch. v11i3. 4248.

\section{How to cite item:}

DH Pasha, S., Muhadar, M., \& Haeranah, H. (2020). Criminal act provision of psychic violence on wife in household scope. Jurnal Cakrawala Hukum, 11(3). 341-350. doi:10.26905/ idjch.v11i3.4248. 


\section{Jurnal Cakrawala Hukum, Volume 11 No. 3 Desember 2020}

ISSN PRINT 2356-4962 ISSN ONLINE 2598-6538

process of proving psychological violence in the household is that no physical evidence can be found in the victim, other witnesses who sometimes refuse to testify because they do not want to interfere in other people's household affairs, there is a long period of time between the incident and the post mortem examination, so the results of the post mortem become less accurate, and the victim does not continue the legal process.

\section{Background}

Psychic violence that occurs in the household is considered merely a "spice" in a marriage even considered normal so that outsiders do not deserve to mix it, even though it is from this psychological violence can develop into other violence. Psychic violence in the household is an act against the law in which the perpetrators should be subject to criminal sanctions (Arini, 2013). The state also holds that all violenceforms, especially domestic violence, are violations of human rights and crimes against human dignity as well as forms of discrimination (the Indonesia Constitution on 1945). Based on Article 5 of Law Number 23 Year 2004 concerning the Elimination of Domestic Violence, it is explained that everyone is prohibited from committing domestic violence against people within household scope means of physical, psychological, sexual violence, and neglect in household.

Judging from some physical violence is the most frequent violence in the household. From the evidentiary aspect, physical violence is easily proven through visum et repertum. Because physical violence is an invisibleeye type. That is, anyone cansee it because happentouch physical among the perpetrators with the victim. Example: slap, punch in, step onfeet, tackle, spit in, freak out, throw with goods, and others (Yanti, 2015). Likewise, sexual violence and neglect of household are relatively similar to physical forms of violence. However, it is different from psychological violence which attacks the victimpsychology, accord-ing to Article 7 of Law Number 23 Year 2004 con-cerning Domestic ViolenceElimination is an act that causes fear, loss of self-confidence, loss of ability to act, sense of inaction helpless, and / or severe psychological suffering on a person.

Provisions for criminal psychic violence in households are regulated in Article 45 of Law Number 23 Year 2004 concerning the Domestic ViolenceEliminationare: (1) Every person who commits a psychological violence act within household scope as referred in Article 5 letter b is convicted with a maximum imprisonment of 3 (three) years or a maximum fine of $\operatorname{Rp~9,000,000.00~(nine~mil-~}$ lion rupiah). (2) In the actscase as referred to in paragraph (1) committed by a husband against a wife or vice versa which does not cause illness or obstruction to carry out occupational positions or livelihood or daily activities, shall be sentenced to a maximum of 4 (four) months imprisonment or a

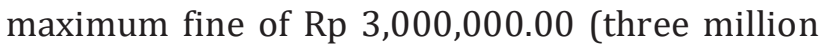
rupiah).

In line with psychological violence, the evidence is carried out in prosecutor the interests to determine the direction of the indictment while for the judge in order to decide the case as fairly as possible (Irawati, 2009). Its meant regarding valid evidence as determined and regulated in Law No. 8 of 1981 concerning the Criminal Procedure Code (KUHAP) in Article 184 paragraph (1) concerning valid evidence in witness statements form, expert statement, letter, instruction, and defendantstatement. Material truth and justice become an objective within the criminal procedure framework so that law enforcement officials are required to act and carry out their duties as the principle realization of rule of law. One form of judges efforts in upholding and searching for and 


\section{Criminal act provision of psychic violence on wife in household scope}

Sri Nurfadillah DH Pasha, Muhadar, Haeranah

finding material truth in completing or deciding a criminal case is by being careful in using evidence in the process of evidence before a court hearing to make light of a criminal act (Waluyadi, 1999).

This research is in line with Resti Arini's (2013) research on Psychic Violence in the Household as a Criminal Act. Difference in Yogyakarta. The research uses normative legal research methods, and data processing techniques by deduction and induction. Likewisewith Dhevid Setiawan (2018) research about Proving Criminal Acts of Psychic Violence in Household Scope. Difference, Place of research in Makassar High Prosecutor's Office with 2013-2016 research year.

One of theevidenceinstruments that investigators can use to uncover psychological violence acts is letter evidence. There are many types of documentary evidence, one of which is a written report made by experts in judicial medicine or commonly known as visum et repertum. Visum et Repertum is divided into 4 types namely (1) Visum et Repertum of Injury (including poisoning), (2) Visum et Repertum of Susila Crime, (3) Visum et Repertum of Corpse, and (4) Visum et Repertum of Psychiatricum (Alfanie, 2017).

In psychological violencecases, Visum et Repertumtype used is the Visum et Repertum Psychiatricum. However, in its development the victims of domestic violence find it difficult to bring the suffering they experience to law enforcement, because of the strong view that the husbands abusive to wives is part of private events (domestic affairs) as well as a lack of knowledge about psychological violence which is a criminal act that can was criminal convicted (Jamaa, 2014). So the authors are interested in knowing more about the process of proving criminal acts of psychological violence that occur within the householdscope.

\section{Method}

Data analysis used is qualitative data analysis in deductive and inductive inference processes form on the dynamics of the relationship between phenomena observed using scientific logic regarding the conduct of criminal acts of psychological violence against wives in the domestic sphere. This researchdata is sociologicalor social legal research, namely research in empirical studies regarding the law workingprocess in society (Suratman, et al, 2013). This research is a sociological juridical research, which is works directly in the field supported by laws and related books. This research type reveals the law that lives in society in everyday life (law in action) (Nazir, 2011).

\section{Discussion}

\subsection{Domestic Violance}

Domestic violence specificity is compared to violenceforms against women, because of the relationship with regard to power (power relationship) between victims and perpetrators. Psychological burden experienced by women victims of domestic violence is very high because power relations always contain elements of trust and also elements of dependency to a certain degree (Muthiah, 2017). In addition to feeling power abuse by the powerowner, victims also generally experience fear, unwillingness, and also too timid to report it to the authorities. As a consequence, domestic violence can never be recorded properly, so the dark number of domestic crimes becomes high.

PatternDomestic Violence tend follow plotacy cleor circle violence over and overtowife (cycle of violence). Cycle violence that first is phase tension. Constitutes violence psychic as insult, scoff and so is phase tension as precondition before violence physical (phase persecution). This is based on the difference between two individuals who come from different families and triggers misunderstanding and commotion between couples (Lestari, 2016). Phase that second is phase persecution where on wife will have violence physical experience caused by her husband. 


\section{Jurnal Cakrawala Hukum, Volume 11 No. 3 Desember 2020}

ISSN PRINT 2356-4962 ISSN ONLINE 2598-6538

Usually, after persecute wife then husband will feel sorry, donate, begging. Furthermore, wife will melted with fhather husband said. Phase that last lyis phase honey month. Where relationship among them back get along well. Lastly, that crucial because from Lots case that happen, after phase month honey end up, cycle violence tend repeated again.

Constitution Removal Violence in House Stairs to show is shifting problem in house stairs, especially related with occurrence violence, that beginning seen as affairs personal among individual and the other in something clumps that named familybecomes affairs country.

\subsection{Lex Specialis Delik Outside the Criminal Code}

Before, there is Article of Law Number 23 Year 2004 concerning the Elimination of Domestic Violence, violence that known in Indonesia law only physical with persecution term. However, after passed Article of Law Number 23 Year 2004 concerning the Elimination of Domestic Violence then appear one act criminal that is violence psychic accompanied with threat criminal tothe culpritthatin a manner explicit not yet there is in Article of Law any even inCriminal Code.

Psychic violence regulated in Article 7 of the Law on the Elimination of Domestic Violence Number 24 of 2004 states that: "Psychic violence is an act that results in fear, loss of self-confidence, loss of ability to act, a sense of helplessness and / or psychological suffering heavy on someone."

This is different from what is regulated in Article 310 to Article 318 of Criminal Code, which only mentions intentionally attacking someone's honor, reputation or committing insults (insults can be categorized as psychological violence). Sounds Article 310 of the Criminal Code are (1) Anyone who intentionally attacks the honor or reputation of a person by accusing something, which means that it is clear so that it is known publicly, is threatened because of pollution with a maximum jail sentence of nine months or a maximum fine of four thousand and five hundred rupiah, (2) If this is done in writing or broadcast, displayed or posted in public, then threatened with written pollution with a maximum imprisonment of one year and four months or a maximum fine of four thousand five hundred rupiah. (3) It does not constitute pollution or written pollution, if the act is clearly done in the public interest or because it is forced to defend itself.

The Criminal Code does not recognize the term domestic violence. This understanding is important to put forward considering the ideology of family harmony adopted by the community so far has not taken the issue seriously and is considered a private matter. While Article of Law Number 23 Year 2004 expressly exists to oppose the act of domestic violence by giving a definition of what is categorized as violence and its variants.

From verses contained in Article 310 of the Criminal Code above, it is very difficult to ensnare perpetrators of Domestic Violencewith that Article. As a perpetrator's actions result towards the victim, it is not mentioned in detail as stated in Article 7 of the Law on the Elimination of Domestic Violence Number 24 of 2004.

In Article 335 of the Criminal Code, which can be categorized into physical and psychological violence. Sounds Article 335 of the Criminal Code as follows: (1) Threatened with a maximum imprisonment of one year or a maximum fine of four thousand five hundred rupiahs; (2) Anyone who unlawfully forces others to do, not do or allow something, by using violence, other acts or unpleasant treatment, or by using threats of violence, other acts or unpleasant treatment, both towards the person himself or someone else; (3) Anyone who forces others to do, not do or allow something with the threat of pollution or written pollution. 
As formulated in item 2, the crime is only prosecuted for the complaint of the person affected. The problem of pollution and unpleasant acts in the Criminal Code can be done physically (with violence) and psychologically (with threats of violence) for everyone. While actions that occur within the scope of the household, only aimed at certain people, namely his wife, children, and people who live in the house.

\subsection{Process of Proving Criminal Acts of Psy- chic Violence in Household Scope}

Types act criminal violence psychic in House stairs regulated in Article $5 b$ of Law Number 23 Year 2004 concerning the Elimination of Domestic Violence that have elements is deed that result in fright, unconfidence, lost ability for act, unempower, and/or suffering psychic weight on someone. In Article 7 of Law Number 23 Year 2004 concerning the Elimination of Domestic Violence set about criminalization violence psychic, good for violence psychic light as well as violence psychic weight.

According to Rosmiati Sain (2019) as Director of Legal Aid for Indonesian Woman in Makassar City that when a victim (woman) came to report to us that sheexperienced domestic violence in this case in the form of psychological violence, the first step we would take was to conduct an interview with the victim to find out how is the chronology of the case. After knowing the chronology, our party will connect or assist the victim to see a psychologist for counseling so that a psychologist's information can be made to support the evidence process if the victim wants to sue the perpetrator of violence (husband) in the District Court or to continue the divorce process in the Religious Court. But in cases of domestic violence that we usually handle, it ends in mediation or divorce. The following is data on domestic violence accompanied by Legal Aid for Indonesian Woman in Makassar from 2015-2018.

Meanwhile, Aibda Darwis (2019) as a representative of PPA (Women's and Children's Services) division that often handles domestic violence issues at the Makassar City Police Resort recognizes that the problem of psychological violence in households is quite difficult to prove. As we know if physical violence will have a scar on the body of the victim while in psychological violence, we cannot immediately see whether the victim is experiencing psychological violence or not. Therefore, in the process of proofing the victim will be asked to show information from a psychologist or psychiatrist as well as an additional witness who saw and heard the incident directly to make it more convincing to make it easier to continue the trial process. The following are data on domestic violence handled by Makassar City Police Resortfrom 2015-2018.

The cause of the lack of cases of psychological violence that entered the trial process in court, the authors conducted an interview with Doddy Hendrasakti (2019) as a Judge in the Makassar District Court explained that in handling cases of

Table1. DataViolenceinHouseStairson2015-2018

\begin{tabular}{ccccccc}
\hline No & Year & $\begin{array}{c}\text { Amount } \\
\text { Case }\end{array}$ & Physical & Psychic & Sexsual & Neglect \\
\hline 1 & 2015 & 9 & 2 & 4 & - & 3 \\
2 & 2016 & 12 & 6 & - & - & 6 \\
3 & 2017 & 12 & 6 & - & - & 6 \\
4 & 2018 & 11 & 5 & 1 & - & 21 \\
Total & 44 & 19 & 5 & 0 & & 21 \\
Source:LBHAPIK,2018 & & & & & & \\
\end{tabular}


psychological violence this is always constrained in proving the cause of domestic violence, especially related to with this psychic is a closed problem that is only known between the defendant and the victim and is as a complaint offense. So there will be known violence if the victim reports it. Then, in the process of proving it is very difficult to find other witnesses because the majority who witnessed cases of psychological violence were the reporter himself. Related to the evidence of psychiatric disorders, sometimes in some cases the victim is late checking her to a psychologist or psychiatrist so that the results of the Visum et Repertum Psychiatricum on the victim are less accurate because it could have been gradually improved during the psychiatric examination so that the victims recorded only mild depression when in fact yesterday, the victim suffered from severe depression. The following is data on domestic violence that finally entered the Makassar District Court from 2015-2018.
Regarding the evidentiary case in court, theLaw Number 23 Year 2004 concerning the Elimination of Domestic Violence stipulates as in Article 55 , that as one of the valid evidences the testimony of a witness is sufficient to prove that the accused is guilty if accompanied by other valid evidences. This implies that the testimony of the victim witness plus one other evidence is sufficient to prove that the defendant is guilty and sufficient for the judge to sentence the defendant.

This article basically contradicts the principle of one witness not a witness (unus testis nullus testis) but a situation regarding the difficulty of proving domestic violence. However, referring to the provisions of Article 103 of the Criminal Code and Article 284 paragraph (2) Criminal Procedure Code and paying attention to the principle of lex specialis derogat legi generalis, it can be said that the principle is unus testis (one witness) do not contradictwith the doctrine of proof in proving criminal acts of domestic violence given the com-

Table2. Data Violence in House Stairson 2015-

\begin{tabular}{ccccccc}
\hline No & Year & $\begin{array}{c}\text { Amount } \\
\text { Cases }\end{array}$ & Physical & Psychic & Sexsual & Neglect \\
\hline 1 & 2015 & 61 & 51 & 1 & - & 9 \\
2 & 2016 & 39 & 25 & - & - & 14 \\
3 & 2017 & 65 & 45 & - & 1 & 19 \\
4 & 2018 & 76 & 57 & 2 & - & 17 \\
Total & & 241 & 178 & 3 & 1 & 59 \\
\hline
\end{tabular}

Source: Makassar City Police Resort,2018

Table 3. Data Violence in House Stairson 2015-

\begin{tabular}{ccccccc}
\hline No & Year & Amount Case & Physical & Psychic & Sexsual & Neglect \\
\hline 1 & 2015 & 24 & 21 & - & - & 3 \\
2 & 2016 & 26 & 25 & - & - & 1 \\
3 & 2017 & 17 & 17 & - & - & - \\
4 & 2018 & 11 & 11 & - & - & - \\
Total & & 78 & 74 & - & - & 4 \\
\hline
\end{tabular}

Source: Court in Makassar City,2018 


\section{Criminal act provision of psychic violence on wife in household scope \\ Sri Nurfadillah DH Pasha, Muhadar, Haeranah}

plexity in determining the evidence of witness testimony in this crime.

According to Riri (2019) as the Functional Prosecutor in the Makassar District Attorney explained that the problem in gathering evidence has always been an obstacle in handling domestic violence cases. For example, to prove that physical violence has taken place, a post mortem must be included. In fact, often the results of the post mortem only show the last violence done to him. For example the victim's body only looks blister or bruised, even though she (the victim) was beaten three months in a row or was tortured for a long time (Adnansyah, 2015). So that previous wounds that were once victim naturally could have healed so they could not be included in the post mortem that was made. Incaseviolencepsychic, the only one way for prove that victim to experience violence is with he made information from psychologist or a psychiatrist whose validity has been guaranteed in accordance with Article 21of Law Number 23 Year 2004 concerning the Elimination of Domestic Violence which states health services to victims.

Visum et Repertum Psychiatricum is one type of post mortem used in the judicial process. Visum et Repertum Psychiatricum is a description of a specialist in psychiatric medicine in the form of a letter as the result of a mental health examination on a person in a health service facility for the purpose of law enforcement (Permenkes RI, 2015). The parties that can propose the making of Visum et Repertum Psychiatricum are as follows: Police, Prosecutors, Courts, and Victims who submit requests to make Visum et Repertum Psychiatricum will be assisted through lawyers who handle the case and then forward it to the investigator.

In examining the victim to prove that the victim had experienced violence which caused disturbance to his psychology, the team was formed by the head of the health facility through a decree from the head of the health service facility. This team consists of 1 (one) Dr. SpKJ (psychiatrist specialist) who is concurrently the team leader and Visum et Repertum Psychiatricum maker and is assisted by a minimum of 2 (two) other health workers including Dr. SpKJ (psychiatrist specialist) others, Dr. Sp (specialist doctors), general practitioners, Psychology Clinical, as well as nursing staff (nurses). Dr SpKJ (psychiatrist specialist) is tasked with conducting a comprehensive psychiatric examination, chairing meetings and summarizing the findings of examinations that have been carried out by other health workers and preparingVisum et Repertum Psychiatricum. Other health workers (Dr. SpKJ (psychiatrist specialist) others, Dr. Sp (specialist doctors), general practitioners, Clinical Psychology, and nursing staff) conduct examinations in accordance with their scientific fields, take notes and record the findings with other team members in drawing up the conclusion of the examination (Permenkes RI, 2015).

Mental health examination activities for law enforcement purposes include (1) psychiatric clinical interviews, (2) psychiatric examinations and observations, (3) psychometric examinations, (4) physical and supportive examinations as indicated, (5) medicolegal analysis, and (6) preparation of Visum et Repertum Psychiatricum.

According to Joko Maharto (2019) as a Psychiatrist in Makassar Bhayangkara Hospital explained that inviolence examining victims process will be accompanied by family and investigators who are equipped with a request letter, police reports, and minutes of victims examination. The inspection method is through interviews, examinations, and observations. In certaincases sometimes it takes around 14 days forvictim observation. In observation process, the victim will be asked to be hospitalized in the hospital to see the progress and also carried out supporting examinations using MMPI (Minnesota Multiphasic Personality Inventory), CT (computed tomography) Scan, MRI (Magnetic Resonance Imaging), Neu- 


\section{Jurnal Cakrawala Hukum, Volume 11 No. 3 Desember 2020}

ISSN PRINT 2356-4962 ISSN ONLINE 2598-6538

ropsychological, and others according to victim needs. However, sometimes in interview meeting it can also be concluded that the victim did indeed experience a mental disorder caused by psychological violence so that it does not require further observation.

The mental examination results will be set forth in the Visum et Repertum Psychiatricum form which includes the history, psychiatric examination and observation results, physical examination results, supporting examinations, conclusions, and conclusions. This Visum et Repertum Psychiatricum is submitted to the requesting agency no later than 7 (seven) working days after the inspection has been completed.

In some cases related to victims who have had such severe trauma that they refuse to attend and explain the incident they experienced, forensic psychiatry can help the police to dig deeper into information about the case being handled. Related to the Visum et Repertum Psychiatricum function that serves as one of the evidence to prove the existence of psychic violence in the household, the author conducted an interview with Riri (2019) as the Functional Prosecutor at the Makassar District Attorney stated that the Visum et Repertum Psychiatricum is a letter made by a psychiatrist doctor who contains a person's psychological explanation as evidence that he has experienced psychological violence. Basically the role of a psychiatric visum et repertum as evidence in the process of proof at the prosecutor's level serves as a reference to determine the demands on how severe or light the article will be given to the defendant. But Visum et Repertum Psychiatricum is a proof that cannot stand alone because it must be supported by other evidence.

Based on psychiatric conditions, the authors conducted an interview with Istiana Tajuddin (2019) as a Psychologist and also a Lecturer at the Faculty of Psychology, Hasanuddin University,
Makassar, explaining to prove that someone experiencing psychological violence we need the help of forensic psychology. The firstthat will be carried out to check the patient's condition is the depth interview to see the synchronization of data provided by the patient. Then check the significant other (partner) to match the iinformationsuitability from the significant other with the victim. In this checking process, the psychologist will measure thevictimdepressionlevelduring the marriage to find out how far the victim has psychological abuse because mental reactions are largely determined by how someone's perception of other people's actions on him. So, when the victim from childhood lives with families who are accustomed to using violence, the threshold for stress is higher than for people born into gentle and polite families. However, the question arises whether when shouted once included psychological violence? Generally, to measure the psychic violencelevel is to see the intensity and frequency of violence that occurs because sometimes yelled at certain problems it is natural because yelling in anger is a reflex action that is sometimes difficult to control. Another case when it turns out it is a habit and style in communicating with their partners. In handling the effects of psychological violence, victims who can be handled by psychologists are victims who can still contact reality or can communicate well and there are not too many physical symptoms caused by mental disorders such as mild depression, insomnia, insecurity, and others. However, when you have entered the severe depression category or commonly referred to as Schizophrenia should consult a Psychiatrist because mental disorders like this need special treatment with drugshelp to overcome the symptoms they are experiencing. It is also important that a sense of family togetherness is needed so that in the future all problems encountered can be resolved in accordance with each family memberexpectations (Manumpahi, 2016). 


\section{Criminal act provision of psychic violence on wife in household scope}

Sri Nurfadillah DH Pasha, Muhadar, Haeranah

\section{Conclusion}

Household problems which were initially seen as private matters between one individual and other individuals are none other than the civil problems stipulated in the Marriage Law, but the rampant domestic violence has made the Government take part in overcoming the problem. Then there is the Lex Specialis offense of psychological violence which is regulated outside the Criminal Code which explains in more detail the consequences of an act and specifically addresses people in the household sphere. In the process of proving psychic violence in the scope of the household must include the Visum et Repertum Psychiatricum made by the psychiatrist and his examination team in order to help the prosecutor to make the indictment and judge in making the fairest decision.

\section{Rerefences}

Adnansyah, Syadri. 2015. Pembuktian Tindak Pidana Kekerasan Dalam Rumah Tangga yang Terjadi di Kota Pare-Pare. Skripsi Tidak Diterbitkan. UNHAS. Makasar.

Aflanie, Iwan. et.al. 2017. Ilmu Kedokteran Forensik dan Medikolegal. Raja Grafindo Persada. Jakarta.

Arini, Resti. 2013. Kekerasan Dalam Rumah Tangga Sebagai Suatu Tindak Pidana. Lex Crimen, Vol. II No. 5. Manado.

Irawati, Dyah. 2009. Rekonstruksi Pasal 44 KUHP dan VeRP Dalam Sistem Peradilan Pidana. Jurnal Hukum Prioris, Volume 2 Nomor 2.

Jamaa, La. 2014. Perlindungan Korban Kekerasan Dalam Rumah Tangga Dalam Hukum Pidana Indonesia. Jurnal Cita Hukum, Vol. I No. 2. Fakultas Syariah dan Ekonomi Islam IAIN Ambon.

Lestari, Sri. 2016. Psikologi Keluarga. Cet IV. Prenada media Group. Jakarta.

Manumpahi, Edwin. 2016. Kajian Kekerasan Dalam Rumah Tangga Terhadap Psikologi Anak. Journal Acta Diurna, Volume V. No.1. Halmahera Barat.
Mayor, George. 2015. Delik Aduan Terhadap Perkara Kekerasan Seksual Dalam Rumah Tangga, Lex Crimen, Vol. IV No. 6, Fakultas Hukum Sam Ratulangi Manado.

Mulyono, G.P., 2017. Kebijakan formulasi tindak pidana pencemaran nama baik dalam bidang teknologi informasi. Jurnal Cakrawala Hukum, 8(2), pp.160170.

Muthiah, Aulia. 2017. Hukum Islam Seputar Hukum Keluarga. Pustaka Baru Press. Yogyakarta.

Nazir, Muhammad. 2011. Metode Penelitian. Ghalia Indo. Bogor.

Peraturan Menteri Kesehatan Republik Indonesia Nomor 77 Tahun 2015 Tentang Pedoman Pemeriksaan Kesehatan Jiwa Untuk Kepentingan Penegakan Hukum.

Ristanty, E., 2018. Kajian Pengaruh Sistem Kekerabatan pada Persepsi Yudisial dalam Menangani Kasus Kekerasan Terhadap Perempuan. Jurnal Cakrawala Hukum, 9(2), pp.127-134.

Setiawan, Dhevid. 2018. Pembuktian Tindak Pidana Kekerasan Psikis Dalam Ruang Lingkup Rumah Tangga. Perbedaan, Tempat penelitian di Kejaksaan Tinggi Makassar dengan tahun penelitian 2013-2016. Pagarayuang Law Journal, Volume 2 No 1 Juli 2018.

Suratman \& Dillah, H. Philips. 2013. Metode Penelitian Hukum Dilengkapi Tata Cara \& Contoh Penulisan Karya Ilmiah Bidang Hukum. Cet. Kesatu. Penerbit Alfabeta. Bandung.

Undang-Undang Dasar Republik Indonesia 1945.

Undang-Undang Nomor 1 Tahun 1946 Tentang Kitab Undang-Undang Hukum Pidana (KUHP).

Undang-Undang Nomor 8 Tahun 1981 Tentang Kitab Undang-Undang Hukum Acara Pidana (KUHAP).

Undang-Undang Nomor 23 Tahun 2004 Tentang Penghapusan Kekerasan Dalam Rumah Tangga.

Waluyadi. 1999. Pengetahuan Dasar Hukum Acara Pidana. Bandung: Mandar.

Wawancara dengan Darwis, Penyidik Anak dan Perempuan Unit PPA Reskrim Polrestabes 


\section{Jurnal Cakrawala Hukum, Volume 11 No. 3 Desember 2020}

ISSN PRINT 2356-4962 ISSN ONLINE 2598-6538

Makassar pada tanggal 18 Desember 2019, Pukul 14.00 Wita.

Wawancara dengan Doddy Hendrasakti, Hakim Pengadilan Negeri Makassar, pada tanggal 6 Desember 2019, pukul 09.00 Wita.

Wawancara dengan Istiana Tajuddin, Dosen pada Fakultas Psikologi Universitas Hasanuddin Makassar, pada tanggal 17 Desember 2019, pukul 14.00 Wita.

Wawancara dengan Joko Maharto, Dokter Psikiater Rumah Sakit Bhayangkara Makassar, pada tanggal 18 Desember 2019, pukul 13.30 Wita.
Wawancara dengan Riri, Jaksa Penuntut Umum Kejaksaan Negeri Makassar pada tanggal 11 Desember 2019, Pukul 10.00 Wita.

Wawancara dengan Rosmiati Sain, Direktur LBH Apik Makassar pada tanggal 9 Desember 2019, Pukul 13.30 Wita.

Yatini, Peran Dunia Pendidikan Dalam Penanganan Pendidikan Anti Kekerasan, Sosialisasi Pendidikan Anti Kekerasan, bagi Aparatur Kesbangpol, Tokoh Masyarakat, Tokoh Agama dan Anggota Tim Terpadu Penanganan Gangguan Keamananse Kota Bontang, 4 Juni 2015. 